\title{
ISLAMIC ACCULTURATION IN THE ANCESTORS' LEGACY OF NANGA SUHAID VILLAGE, WEST KALIMANTAN
}

\author{
B I B I S U PRIAN TO \\ Fakultas Tarbiyah dan IImu Keguruan Institut Agama Islam Negeri (IAIN) Pontianak \\ JI. Letjen Soeprapto No. 19. Pontianak. Email: bibisuprianto78@gmail.com
}

\begin{abstract}
This paper attemps to describe how Islamic acculturation was formed in the tradition of Nanga Suhaid Village, West Kalimantan. This paper shed light on community activities in relation to religious interactions, especially in the inner part of the West Kalimantan region, namely Suhaid Sub-district Nanga Suhaid village, Kapuas Hulu district. This study utilized observation, interview, and documentation for data collection through the lens of an anthropological perspective. The results of the study showed: 1) practice of the tradition in the Suhaid village that has long been carried out is a means to maintain the existing traditions. 2) the expression of Islamic Da'wah values could be seen from "buang-buang", plain flour, circumcision, customary law, fruit and da'wah values. 3) The tradition of maintained tolerance within the community to create peace and harmony in the community.
\end{abstract}

KEY WoRDS: tradition, dakwah values, Islamic acculturation.

\section{AKULTURASI ISLAM PADA TRADISI NENEK MOYANG DI DESA NANGA SUHAID, KALIMANTAN BARAT}

\begin{abstract}
Abstrak
Makalah ini berupaya mendeskripsikan akulturasi Islam pada tradisi nenek moyang di Desa Nanga Suhaid, Kalimantan Barat. Makalah ini berfokus pada kegiatan-kegiatan masyarakat dan interaksi agama yang saling mendukung khususnya daerah pedalaman kepulauan Kalimantan Barat Kecamatan Suhaid, Desa Nanga Suhaid Kabupaten Kapuas Hulu. Penelitian ini menggunakan metode wawancara, observasi dan dokumentasi serta pendekatan antropologis pada masyarakat. Hasil penelitian 1) Penerapan tentang tradisi-tradisi Desa Suhaid yang telah dilaksanakan sebagai gambaran budaya setempat untuk mempertahankan tradisi yang telah ada. 2) Mengambil nilai-nilai dakwah Islam yang ada pada tradisi seperti buang-buang, tepung tawar, sunatan/ khitanan, hukum adat, beruah dan nilai-nilai dakwah. 3) Akulturasi Islam pada tradisi nenek moyang yang selalu menjaga toleransi sesama agar terciptanya kedamaian dan ketentraman pada masyarakat.
\end{abstract}

KATA KUNCI: tradisi, nilai-nilai dakwah, akulturasi Islam.

* Naskah diterima Agustus 2020, direvisi Oktober 2020, dan disetujui untuk diterbitkan November 2020 


\section{A. Pendahuluan}

Islam adalah agama yang senantiasa menerima akan kehidupan budaya pada setiap perkembangan zaman. Sementara itu sebagian akademisi muslim lebih terlena mengamati perkembangan pemikiran Islam pada tokohtokoh dibandingkan mengamati perkembangan kehidupan masyarakat muslim di lapisan bawah. (Yusriadi, 2014). Perkembangan zaman tentu tidak mengubah tradisi yang ada pada suatu daerah. Tradisi yang berasal dari roh nenek moyang kini tetap dipercayai masyarat setempat. Keseimbangan kosmos adalah terjaganya hubungan yang harmonis antara mikrokosmos (manusia) dan makrokosmos (tuhan atau dunia gaib) (Sutiyono, 2011). Islam yang berwatak dengan budaya lokal kini melekat pada masyarakat dan diterima sebagai agama baru. Sulit dipungkiri bahwa Islam sebagai agama yang diterima di Nusantara (cikal bakal Indonesia) berkembang selaras dengan penerimaan atas nilainilai kearifan lokal tanpa meninggalkan jejak pertentangan sedikitpun (Kurniawan, 2018). Dalam hal ini telah jelas bahwa agama Islam tetap menerima suatu budaya lokal yang berkaitan dengan proses sosial. Proses sosialisasi berkaitan dengan proses belajar kebudayaan dalam hubungan dengan sistem (Nuriyanto, 2017). Hal ini juga sejalan dengan pengertian bahwa kesadaran budaya adalah sikap seseorang individu yang mampu menghargai, memahami dan menghormati perbedaan budaya dirinya dengan budaya lain di luar dirinya (Mumtazul, 2017). Sehingga dengan adanya tradisi dapat menghormati suatu kebudayaan daerah setempat.

Islam adalah agama yang memiliki perbedaan-perbedaan pendapat serta warna yang berbeda-beda. Warna inilah yang menjadi corak suatu agama menerima ataupun tidak tentang kepercayaan terhadap tradisi roh nenek moyang pada zaman sekarang. Sebuah tradisi hasil hibridasi atau perkawinan antara Islam di satu sisi serta tradisi lokal pada sisi lain (Nuryah, 2016). Sehingga dengan kepercayaan tersebut timbullah keyakinan bahwa tradisi setempat dapat dipertahankan ataupun tidak. Tradisi inipun bermula dari orang-orang terdahulu yang dulunya adalah agama Hindu dan Buddha, yang kini diIslamisasikan menjadi agama Islam sehingga tradisi Buddha dan Hindu tetap dipertahankan.
Mayoritas Islam di Kalimantan Barat menganggap diri mereka sebagai suku Melayu, walaupun dari nenek moyang mereka, dulunya adalah orang Dayak ataupun Iban yang beragama Hindu-Buddha. Dapat dikatakan bahwa kebudayaan Melayu yang diamalkan oleh masyarakat Kalimantan Barat, pada mulanya menunjukkan perpaduan tradisi setempat yang terlebih dahulu dipengaruhi oleh Hindu-Buddha dan kemudian oleh Islam (Hermansyah, 2012). Maka tradisi Hindu-Buddha merupakan tradisi yang telah hadir dahulu dari Islam.

Dalam tradisi Islam yang bercorak HinduBuddha masyarakat mempercayai bahwa roh nenek moyang tetap hidup di antara mereka. Hal ini digambarkan dalam suatu peristiwa ketika seorang anak ingin melaksanakan tradisi besunat, kemudian melakukan tradisi buang-buang, tepung tawar, dan lain-lainnya.

Sebelum itu adat ini biasanya dilakukan oleh masyarakat Desa Nanga Suhaid Kecamatan Suhaid Kabupaten Kapuas Hulu Provinsi Kalimantan Barat. Masyarakat Suhaid menganggap diri mereka sebagai suku Melayu dengan jumlah 99\% di Desa Nanga Suhaid.

Tulisan ini membicaran tentang Islam yang ada di Desa Nanga Suhaid Kecamatan Suhaid Kabupaten Kapuas Hulu Provinsi Kalimantan Barat. Yang menggambarkan tradisi penduduk Islam yang sekarang masih dikatakan bercorak Hindu-Buddha. Berbicara tentang awal pengaruh Hindu-Buddha di Nusantara sejauh ini selalu dimulai pada sekitar abad ke-5 M. yang ditandai oleh kehadiran kerajaan Kutai dan Tarumanagara di Nusantara dan masih sedikit perhatian terhadap periode sebelum itu (Indradjaja, 2014). Selain itu dalam penelitian ini juga membahas tentang Buang-buang, Tepung Tawar, dan adat pernikahan yang ada di Desa Suhaid, tradisi ini tidak hanya dimiliki oleh desa Nanga Suhaid Kecamatan Suhaid Kabupaten Kapuas Hulu, Kalimantan Barat tetapi juga ada di Desa Dabong Kabupaten Kubu Raya, Kalimantan Barat yang telah ditulis oleh Saripaini dan Yusriadi dalam jurnal khatulistiwa identitas orang Bugis di Dabong. Sehingga dengan persamaan tersebut tulisan ini menjelaskan Islam yang bercorak Hindu-Buddha.

Dalam tulisan ini memuat tiga konsep yang menjadi tradisi di pada Masyarakat Suhaid. Pertama, proses tradisi adat pada masyarakat 
Melayu Islam di Suhaid Desa Nanga Suhaid. Proses ini dilakukan dengan berbagai langkah dan cara memenuhi tradisi yang ada. Walaupun terdengar aneh tradisi tetaplah menjadi hal yang biasa bagi penduduk setempat. Sehingga dengan adanya tradisi tersebut kita mengetahui bahwa banyak peninggalan tradisi yang harus diketahui.

Kedua, yaitu makna melakukan tradisi adat Desa Suhaid yang merupakan sebuah hubungan antara manusia dan alam yang mengakibatkan sebuah persatuan dalam kehidupan.

Ketiga, hal yang penting diketahui dalam Islam bercorak Hindu-Budda pada tradisi adat Desa Nanga Suhaid yaitu sebagai tanda bahwa keluarga yang memenuhi ataupun melaksanakan tradisi tersebut sebagai hajat pada seseorang yang melakukan pernikahan, sunatan, maupun melahirkan.

Dalam hal ini budaya merupakan aset yang dilahirkan oleh suatu negara, negara inilah yang kemudian mendata kembali tradisi-tradisi yang mungkin menjadi suatu peristiwa penting yang harus diingat bahkan diluruskan kembali.

Di zaman sekarang banyak para pemuda tidak mengetahui bagaimana proses yang dilakukan masyarakat tentang tradisi setempat, apakah tradisi tersebut menjadi hal yang sirik bagi masyarakat ataupun tidak dan untuk apakah tradisi ini dilakukan. Hal ini menjadikan tanggung jawab bagi pemerintah untuk memperkenalkan kembali tradisi yang telah melekat pada orangorang tua sehingga ketika pemahaman baru yang dibawa oleh pemuda tidak bertentangan dengan mereka yang mengakibatkan perkelahian antar warga itu terjadi.

Namun sangat disayangkan jika Islam yang bercorak Hindu-Buddha ini menjadi sorotan yang tidak baik di mata masyarakat ataupun pemerintah, sehingga perlu kajian yang serius bagi masyarakat setempat. Walaupun agama Islam sudah identik dengan kemelayuan namun kepercayaan yang bercorak lokal masih dapat dilihat jejaknya dalam sejumlah upacara. Seperti yang berkaitan dengan sesaji yang diletakkan di bawah pohon besar atau dihanyutkan ke sungai (Hermansyah, 2012). Hal inilah menggambarkan bahwa tradisi Hindu-Buddha tetap ada di kalangan Islam.

\section{B. Metode Penelitian}

Penelitian akulturasi Islam pada tradisi nenek moyang di Desa Nanga Suhaid, Kalimantan Barat menggunakan metode wawancara, observasi, dan dokumentasi agar dapat mengetahui bagaimana tata cara tradisi dan ritual yang dilakukan masyarakat muslim desa Nanga Suhaid. Penelitian ini mengidentifikasi nilai-nilai dakwah dan akulturasi Islam pada masyarakat setempat melalui empat tradisi seperti buang-buang, tepung tawar, sunatan dan beruah. Tujuannya agar mengetahui akulturasi Islam pada tradisi nenek moyang. Pendekatan yang digunakan yaitu pendekatan antropologis kemasyarakatan yaitu, melihat proses awal dari pembuatan sesaji buangbuang seperti bahan yang disiapkan, proses pembuatan tepung tawar yang diikuti dengan selamatan dan doa bersama. Kemudian, melihat langsung proses acara sunatan pada tradisi masyarakat setempat dan meminta dokumen adat pernikahan.

Dalam hal ini peneliti melihat wujud praktek keagamaan dan tradisi yang tumbuh serta berkembang dalam masyarakat. Lokasi bertempatan di Desa Nanga Suhaid Kecamatan Suhaid Kabupaten Kapuas Hulu Provinsi Kalimantan Barat. Waktu penelitian yaitu pada tanggal 6-19 Juli 2020. Ketika itu mengambil data pada tangga 6 Juli tentang proses pembuatan bahan buang-buang yang dilakukan oleh beberapa orang di desa, kemudian pada tanggal 7 Juli hajatan mengundang pemangku agama, tukang tawar, dan medis keperawatan bagian sunat-menyunat. Kegiatan ini juga mengundang berbagai orang mulai dari keluarga dan masyarakat setempat. Dalam kegiatan ini masyarakat yang diundang pada acara sunatan menganggap kegiatan ini biasa-biasa saja. Begitupula dengan masyarakat setempat yang diwawancarai mengenai tradisi tersebut.

Tentu agar penelitian ini berjalan dengan lancar dan sesuai dengan rencana, dan data yang diperlukan terkumpul dengan mudah, maka peneliti memanfaatkan waktu luang informan untuk melakukan wawancara secara pendekatan antropologis kepada salah satu masyarakat Desa Nanga Suhaid yaitu Cikdemui, menanyakan tradisi beruah kepada Hasan Basri ketua RT, pada tanggal 23 September, 27 September 2020, dan 4 Oktober 2020 kembali mengambil informasi kepada Ngah Syarief selaku jamaah masjid, H. Abdul Ghani Ketua Masjid Baitul Rahman, Habibi perwakilan remaja Masjid di Almuttaqien Desa 
Suhaid, Ibu Juleha perwakilan warga Desa Tanjung dan Akbar perwakilan remaja masjid Baitul Rahman Dusun Tanjung Kapuas. Hal ini dilakukan oleh peneliti dengan harapan para informan dapat membantu memberikan informasi yang diperlukan dalam penelitian ini.

Gambar 1. Peta Letak Kecamatan Suhaid.

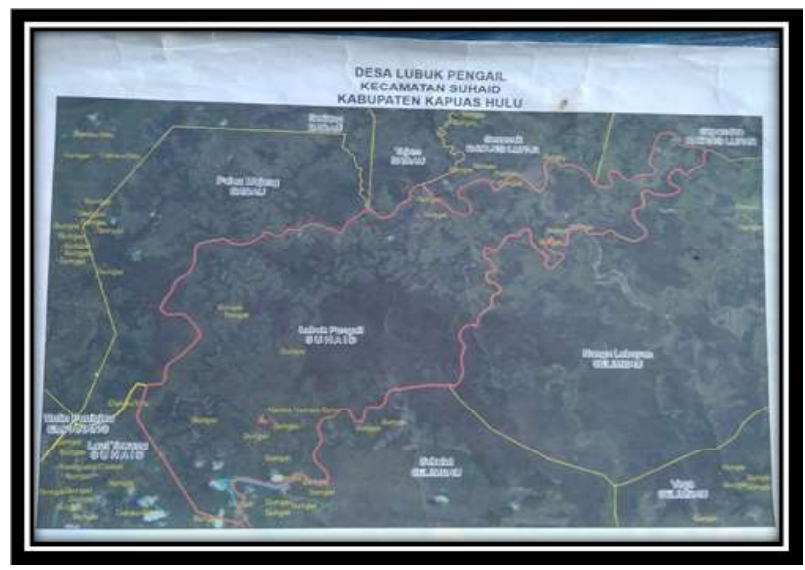

Peta Kecamatan Suhaid Kabupaten Kapuas Hulu Provinsi Kalimantan Barat tempat penelitian dilakukan.

Adapun alasan penelitian ini dilakukan di Kecamatan Suhaid Desa Nanga Suhaid Kabupaten Kapuas Hulu Provinsi Kalimantan Barat yaitu mengangkat trdisi-tradisi yang ada di Kecamatan Suhaid, mengenalkan Islam yang beralkulturasi pada Desa Nanga Suhaid. Mencerminkan sikap toleransi antara agama dan budaya. Dalam hal ini peneliti mengambil dua jenis data yaitu primer dan sekunder. Data primer menyangkut segala informasi, fakta, dan realitas yang terkait di Desa Nanga Suhaid seperti halnya wawancara dan foto tradisi dilaksanakan. Sedangkan data sekunder yaitu berupa buku dan jurnal-jurnal yang terkait masalah Islam yang beralkulturasi.

Pengumpulan data yaitu mewawancarai proses tradisi buang-buang bersama salah satu masyarakat setempat yaitu Cikdemu, kemudian mendokumentasikan segala peristiwa yang dilaksanakan pada proses buang-buang sampai hajatan yang dilakukan seperti tepung tawar dan sunatan. Selain itu peneliti mewawancarai tentang tradisi beruah yang dilakukan oleh masyarakat setempat dengan mengambil informal dari 3 orang, 2 di antaranya remaja masjid yaitu Habibi dari masjid Almuttaqien Suhaid, Akbar remaja masjid Baitul Rahman dan Hasan Basri ketua RT Dusun Tanjung Hilir Desa Nanga Suhaid.

Kemudian menganalisis data menggunakan pengumpulan data, reduksi data, penyajian data serta menarik kesimpulan.

\section{Hasil dan Pembahasan}

Kecamatan Suhaid Kabupaten Kapuas Hulu adalah desa yang memiliki jumlah penduduk $70 \%$ sebagai Muslim/Islam. Suku terbesar di Kecamatan Suhaid merupakan suku Melayu. Suhaid merupakan desa pedalaman yang mayoritas masyarakat penduduk bekerja sebagai nelayan, bisnis, dan Meladang. Selain itu Desa Suhaid juga dikenal dengan sebutan Bumi Arwana. Bumi di mana tempatnya ikan Arwana dibudidayakan menjadi ladang bisnis bagi masyarakat setempat. Menurut Badan Pusat Statistik Kabupaten Kapuas Hulu (2018) tercatat Kecamatan Suhaid, secara astronomis berada pada $0,50^{\circ} \mathrm{LU}-0,68^{\circ} \mathrm{LU}$ (garis lintang) dan $111,98^{\circ}$ sampai $112,11^{0}$ Bujur Timur. Secara geografis, batas-batas Kecamatan Suhaid seperti sebelah utara berbatasan dengan Kecamatan Batang Lupar, sebelah Selatan berbatasan dengan Kecamatan Seberuang, sebelah barat berbatasan dengan Kecamatan Semitau, dan sebelah timur berbatasan dengan Kecamatan Selimbau.

Selain itu dalam Badan Pusat Statistik Kabupaten Kapuas Hulu (2018) menjelaskan letak luas wilayah Kecamatan Suhaid merupakan kecamatan dengan luas wilayah $74.484 \mathrm{Ha}$, serta dengan 2,08\% dari luas Kabupaten Kapuas Hulu secara keseluruhan yang mencapai $29.842 \mathrm{~km}^{2}$. Dari 11 desa yang ada, desa Kerangas, Nanga Suhaid, dan Mantan merupakan tiga desa yang memiliki luas wilayah terbesar dengan luas masing-masing $17.516 \mathrm{Ha}, 15.200 \mathrm{Ha}$ dan 14.476 Ha atau setara dengan $23.52 \%, 20,41 \%$ dan $15,26 \%$ dari luas Kecamatan Suhaid. Sedangkan Desa Nanga Suhaid merupakan desa dengan luas wilayah terkecil dimana luas wilayah desa tersebut $6.073 \mathrm{Ha}$ atau 8,15\% luas wilayah Kecamatan Suhaid. 
Tabel 1. Letak Geografis Kec. Suhaid.

\begin{tabular}{cc}
\hline $\begin{array}{c}\text { Garis Lintang } \\
\text { Latitude }\end{array}$ & $\begin{array}{c}\text { Garis Bujur } \\
\text { Longitude }\end{array}$ \\
\hline $0,50^{\circ} \mathrm{LU}-0,68^{\circ} \mathrm{LU}$ & $111,98^{\circ} \mathrm{BT}-112,11^{\circ} \mathrm{BT}$ \\
\hline
\end{tabular}

Tabel 2. Batas Administrasi Kec. Suhaid

\begin{tabular}{cc}
\hline Batas Administrasi & $\begin{array}{c}\text { Berbatas dengan } \\
\text { Administration Border }\end{array}$ \\
\hline Sebelah Utara/ North & Kecamatan Batang \\
Sebelah Barat/ West & Lupar \\
jebelah Selatan/ South & Kecamatan Semitau \\
Sebelah Timur/ East & Kecamatan Seberuang \\
& Kecamatan Selimbau \\
\hline
\end{tabular}

Sumber 1 dan 2: Badan Pusat Statistik Kabupaten Kapuas Hulu 2018.

Begitu pula dengan jumlah penduduk pada Desa Suhaid yang dijelaskan dalam tabel berikut.

Tabel 3. Jumlah Penduduk Suhaid

\begin{tabular}{ccccc}
\hline No & JUMLAH & $\begin{array}{c}\text { JUMLAH } \\
\text { PENDUDUK }\end{array}$ & $\begin{array}{c}\text { SEX } \\
\text { RATIO }\end{array}$ \\
\hline & \multicolumn{4}{c}{} \\
& Kk & Laki-laki & Perempuan \\
1 & 784 & 1.435 & 1.357 & 105.75 \\
\hline
\end{tabular}

Sumber: Badan Pusat Statistik Kabupaten Kapuas Hulu 2018

Data tersebut menjelaskan jumlah penduduk desa Nanga Suhaid yang dirilis oleh Badan Pusat Statistik Kabupaten Kapuas Hulu pada tahun 2018 sebanyak 2.792 dengan jumlah Kartu Keluarga sebanyak 784 .

Kecamatan Suhaid salah satu daerah yang termasuk dalam Islamisasi, hal ini terlihat dari proses terbentuknya kerajaan di Kecamatan Suhaid. Penyebaran Islam di Hulu Sungai Kapuas semakin intensif dilakukan oleh Pengganti Sultan Nata yakni Ade Abdurrahman alias Abang Pikai dan bergerlar Sultan Abdurrahman Muhammad Jalaluddin atau Sultan Aman, yang memerintah tahun 1150 sampai 1200 H (1737-1785 M), Sultan ini turut serta dalam penyebaran agama Islam ke kawasan hulu Sungai Kapuas bersama penghulu agama kerajaan yang bernama Madil bin Luwan, selanjutnya usaha dakwah ini semakin kuat ketika penguasa kerajaan Silat, Suhaid, Selimbau, Piasak, Jongkong dan Bunut menganut agama Islam (Hermansyah, 2012). Hampir Semua kawasan di pusat kebudayaan Melayu (misalnya ibu kota kecamatan) mengenal konsep menjadi Melayu atau masuk Melayu istilah ini merujuk kepada orang yang memeluk agama Islam (Yusriadi, 2018).

Sedangkan data mayoritas agama sebagai berikut.

Tabel 4. Jumlah Penganut Agama di Kecamatan Suhaid

\begin{tabular}{cccccc}
\hline \multicolumn{6}{c}{ AGAMA } \\
\hline Islam & Khatolik & Protestan & Hindu & Buddha & Konfhchu \\
6.843 & 983 & 1.512 & 0 & 0 & 0 \\
\hline
\end{tabular}

Sumber: Buku Putih Sanitasi (BPS) Kabupaten Kapuas Hulu 2013

Dalam angka tersebut menjelaskan bahwa penduduk di Kecamatan Suhaid memiliki penganut agama Islam tertinggi dengan jumlah 6.843 orang. Angka tersebut diambil pada tahun 2013 dan belum ada jumlah yang di update pada tahun 2020. Sehingga dapat dikatakan bahwa munculnya parakerajaan di kecamatan dan masuknya Islam di pedalaman mengakibatkan terjadinya Islamisasi daerah dan dapat dikatakan mayoritas Kecamatan Suhaid adalah agama Islam melalui Islamisasi pendalaman. Islam juga berhasil diperkenalkan pada masyarakat Dayak yang sebelumnya tidak mengenal Islam, hal ini terbukti dengan banyaknya ditemukan kampungkampung Dayak Islam, juga orang Melayu yang dulunya dari suku Dayak sebelum memeluk Islam dan mengakui dirinya sebagai Melayu setelah memeluk agama Islam (Efendi, 2017). Sehingga mengakibatkan terjadinya Islam yang toleren akan budaya nenek moyang yang ada.

\section{Tradisi Buang-Buang}

Buang-buang tradisi Kabupaten Kapuas Hulu Provinsi Kalimantan Barat khususnya Kecamatan Suhaid Desa Nanga Suhaid adalah proses menghormati roh nenek moyang yang telah tiada. Tradisi ini sama halnya dengan tradisi sedekah laut pada masyarakat Jawa Wonokerto Kabupaten Pekalongan yang mengatakan tradisi sedekah laut sebelumnya sering disebut sebagai nyandran laut yaitu membuang atau melarung sesaji ke tengah laut (Widati, 2011). Jika kita berpacu pada 
perkembangan zaman mungkin tradisi ini sudah tidak bisa dilaksanakan kembali karena merupakan tradisi kuno tapi beda dengan desa Kecamatan Suhaid yang tetap melaksanakan tradisi buang-buang tersebut.

Buang-buang adalah tradisi sesaji yang dilakukan masyarakat Kabupaten Kapuas Hulu, tradisi tersebut dapat dilihat sebagai berikut.

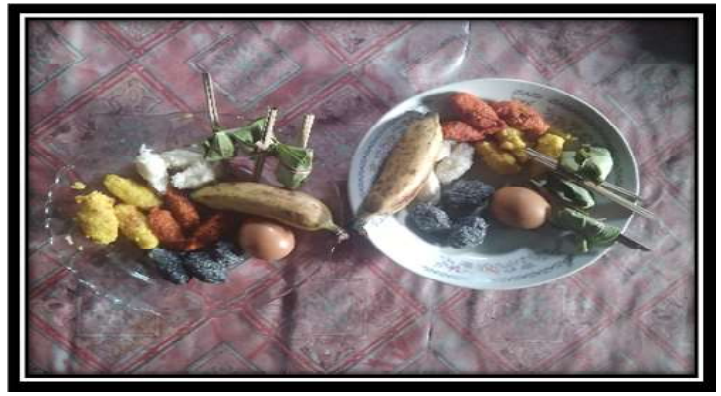

Gambar 2. Sesaji Buang-buang.

Pada gambar tersebut menjelaskan bahanbahan yang diperlukan masyarakat dalam melaksanakan ritual buang-buang seperti halnya nasi dikepal menjadi tiga warna dan tiga rangkap yaitu warna putih, hitam dan kuning, daun rokok dimasukkan dengan buah pinang, kapur sirih, tembakau Jawa dijadikan satu dibuat tiga batang dalam dua rangkap, kemudian masukkan ke dalam piring dalam jumlah yang sama. Latar kultural pengadaan sesaji ini adalah sistem pengetahuan dan sistem peralatan hidup dan teknologi yang masih sederhana (Baehaqie, 2017).

Setelah sesaji selesai dibuat oleh keluarga yang ingin berhajat, barulah dihantarkan ke darat dan ke sungai dengan membaca mantra 'bismillah nusah ngaru kami bah" yang artinya dengan menyebut nama Allah dan meminta pertolongan kepada-Nya wahai ruh jangan mengganggu kami (Cikdemui, wawancara 6 Juli 2020). Buang-buang salah satu tradisi yang dimiliki oleh agama HinduBuddha yaitu seperti budaya Bali dan Jawa. Sesajen merupakan identitas budaya, akultrasi dan kearifan lokal masyarakat tradisional di Indonesia, dengan menunjukkan daerah yang masih kental akan budaya sesajen ialah, Jawa, Bali (Adam, Yusup, Fadlullah, Nurbayan, 2019).

Proses sesaji yang dilakukan masyarakat Suhaid semata-mata berniat meminta pertolongan Allah sekaligus menjaga hubungan dengan alam dengan cara berniat memberikan sedekah, seperti halnya buang-buang yang dilakukan di dalam air untuk memberikan makanan bagi hewan yang ada di air yaitu ikan-ikan. Kemudian di darat memberikan makanan kepada hewan-hewan yang ada di darat, baik itu semut maupun hewan yang ada di darat. Sedangkan melalui wawancara dengan Jamaah Masjid Ngah Syarief (23-09-2020) mengatakan buang-buang sering dilakukan masyarakat Suhaid, sebenarnya hal tersebut dilakukan karena nenek moyang dulu takut akan arwah ataupun setan di air dan di darat. Ngah Syarief juga mengatakan ada sebagian orang yang masih percaya dan juga tidak percaya sekarang. Dengan niat tersebut tidak menimbulkan kesirikan kepada Allah Swt. Maka dapat dikatakan bahwa budaya buang-buang ataupun sesajen di masyarakat Melayu Islam Nanga Suhaid merupakan budaya Hindu-Buddha yang kini masih dipertahankan oleh masyarakat setempat. Dan hal ini telah menjadi akulturasi pada tradisi yang dilakukan oleh orang-orang Islam.

Setelah proses buang-buang tersebut dilakukan besoknya keluarga yang bersangkutan melakukan hajatan sunatan kepada anaknya. Sunatan tersebut dilakukan dengan proses adat kembali yaitu dengan cara membuat daun penawar atau tepung tawar.

\section{Tepung Tawar}

Daun penawar adalah proses dimana sang anak yang ingin besunat terlebih dahulu dikasih dengan tepung tawar. Kegiatan ini adalah tradisi Desa Nanga Suhaid yang telah dilakukan saat oleh keluarga memenuhi hajatan. Bahan-bahannya yaitu daun pandan, beras kuning, talam, serta pisau kecil yang diselipkan dalam talam. Sebagaimana gambar berikut ini.

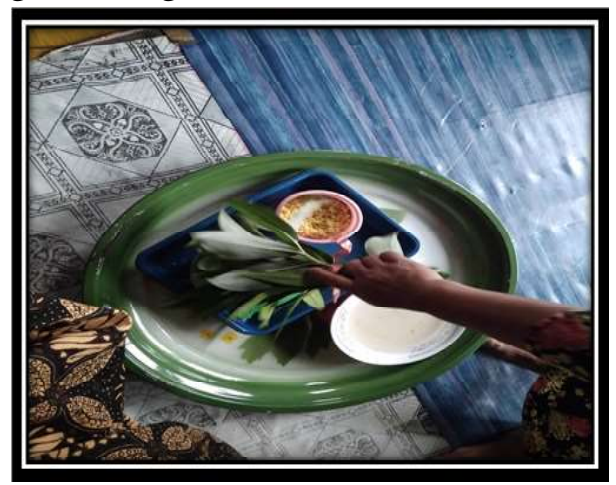

Gambar 3. Tepung Tawar

Setelah daun penawar disiapkan maka dari pemuka agama setempat membacakan doa 
selamat dan tolak bala beserta dengan shalawat kepada baginda Nabi Muhammad Saw. Ritual tolak bala mengandung kepercayaan terhadap adanya kekuatan alam yang harus didukung dan dipertahankan untuk mencari jalan terbaik dalam meneruskan kehidupan sehari-hari masyarakat agar dijauhkan atau terhindar dari marabahaya. (Hasbullah, Tayo, Pawi, 2017). Sejalan dengan ini menurut H. Abdul Ghani selaku ketua masjid Baitul Rahman (wawancara, 23 September 2020) mengatakan tepung tawar merupakan tradisi Suhaid yang biasanya kegiatan tersebut meminta keselamatan dan tolak Bala. One of the volues of Islam reffered in this local tradition is concerned with the beginning of the ceremony where the begins with reciting basmalah and al-fatihah and ends with sholawat to the Prophet (Ibrahim, 2018). Doa-doa tersebut sebagai rasa syukur dan meminta perlindungan kepada Allah serta menghormati rasul sebagai suri tauladan masyarakat. Praktik ritual tepung tawar merupakan salah satu upaya orang Bugis dalam menolak bala, membuang sial yang pada zaman dahulu dilakukan atas dasar kepercayaan terhadap gangguan roh nenek moyang, tradisi tepung tawar telah menjadi kebiasaan masyarakat Melayu-Bugis (Saripainai dan Yusriadi, 2016). Tradisi tersebut sebenarnya dimiliki oleh agama lain tapi saat Islam masuk dengan cara damai maka ritual tepung tawar tersebut berakulturasi bersama dengan cara Islam. Seperti dalam tepung tawar, masyarakat Banjar mewarnai tradisi melalui penggantian manteramantera penyembuhan maupun doa-doa keselamatan yang dibacakan ketika prosesi sedang berjalan (Royyani, 2014). Begitu pula dengan adat tepung tawar yang dilaksanakan di masyarakat Kecamatan Suhaid yang menjadikan tradisi ini sebagai tradisi meminta keselamatan kepada Allah Swt serta meminta perlindungan dari segala musibah. Inilah yang dinamakan dengan akulturasi budaya yang dilakukan Islam.

\section{Tradisi Sunatan/ Khitanan pada Masyarakat}

Tradisi sunatan di Desa Nanga Suhaid Kecamatan Suhaid Kabupaten Kapuas Hulu biasanya dilakukan ketika anak masih berusia muda berkisar 9 tahun. Tradisi tersebut dilakukan sebelum anak tersebut menginjak usia balig ataupun remaja, kadang juga saat anak tersebut sudah berumur 8 tahun. Khitan atau yang sering dikenal dalam masyarakat sebagai sunatan bisa dipandang dari dua perspektif, budaya dan agama (Bangun dan Berutu, 2013). Dalam budaya Kecamatan Suhaid tradisi sunatan selalu diringi dengan doa selamat dan tolak bala untuk seseorang yang akan disunat. Ngah Syarief mengatakan (wawancara, 28 September 2020) tradisi besunat benar dibacakan dengan doa selamat dan tolak bala agar si pasien (atau anak yg besunat) diberikan keselamatan dan dihindari dari bala atau musibah, selain itu tidak ada doa yang lain dibacakan. Setelah itu barulah hajatan besunat dilaksanakan dan masyarakat yang hadir mengunjungi hajatan sunatan dihidangi dengan makanan yang telah disiapkan sebagai rasa syukur telah melaksanakan tradisi sunatan. Nico Kaptein has argued that both female circumcision and male circumcision were indigenous cultural features in the Indonesian archipelago that had origin in preIslamic times (Oktavia, 2014).

Hal ini telah menjadi kebiasaan bagi penduduk setempat yaitu mengkhitan anaknya di usia muda karena ketakutan mereka akan proses masuknya balig yang begitu cepat dikalangan anak-anak, ketika sudah balig anak tersebut diperkirakan akan merasa malu ketika ingin disunat. Yang mana menurut Ibu Juleha salah satu warga Desa Tanjung (wawancara, 27 September 2020) mengatakan memang benar jika anak tersebut sudah besar mereka akan merasa malu dalam arti normal menyadari dirinya telah terlalu besar untuk disunat.

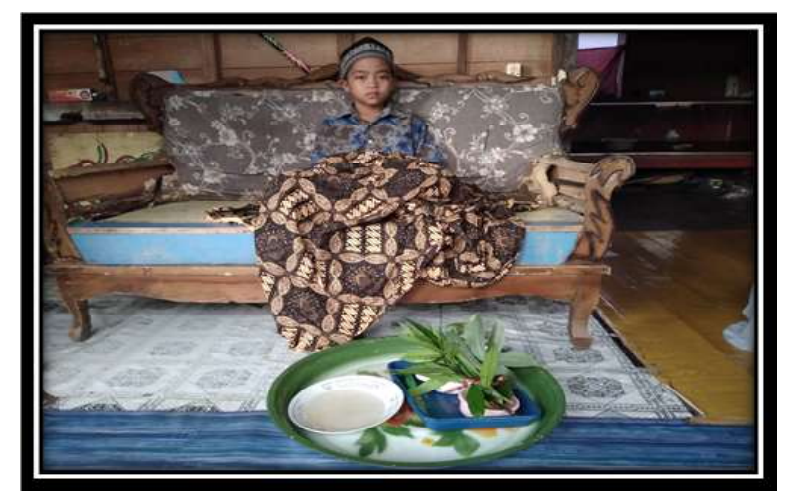

Gambar 4. Upacara Sunatan Anak.

Sebelum seorang anak disunat terlebih dahulu anak tersebut diberikan penawar dengan cara memercikkan air menggunakan daun dan bahan-bahan penawar yang telah disiapkan dan dibaca dengan doa selamat dan tolak bala.

Langkah yang dilakukan yaitu memercikkan 
air menggunakan daun pandan di sebelah kanan bahu, sebelah kiri bahu dan bagian ubun-ubun di kepala, setelah itu ditempelkan dengan pisau di sebelah kiri dan kanan bahu dan kepala, kemudian ditaburkan beras kuning dengan langkah yang sama. Setelah proses tersebut dilakukan barulah sang anak tersebut boleh untuk disunat oleh menteri ataupun seorang medis yang ahli di bidang sunat-menyunat. Tidak bisa dipungkiri bahwa Islam yang dibawa oleh para ulama telah mengajarkan ajaran toleransi kepada masyarakat yang baru memeluk ajaran agama Islam seperti halnya tepung tawar yang sampai saat ini masih dipertahankan oleh masyarakat Desa Nanga Suhaid walaupun bukan termasuk budaya Islam. Inilah yang dinamakan dengan anugerah dalam setiap tradisi sunatan.

Sama dengan tradisi sunatan, untuk memahami akulturasi Islam melalui tradisi yang ada di Dusun Tanjung Desa Nanga Suhaid dapat dilihat dari tradisi pernikahan. pernikahan dilaksanakan masyarakat setempat melalui tradisi buang-buang terlebih dahulu. Selain itu untuk masyarakat setempat harus memenuhi adat istiadat yang berlaku. Seperti halnya dalam buku adat Istiadat desa Nanga Suhaid (2006) pasal 5 yang menjelaskan setelah resmi menjadi suamiistri pernikahan kedua belah pihak, maka pihak laki-laki wajib membayar seperangkat barang seperti, pakaian sebesar Rp. 100.000,-, satu buah tempayan kapat, satu buah cincin penyawak/ kawin untuk istri, satu bukur tembaga, satu buah beliung, satu buah pisau, pesalin dara (satu kain satu baju dan satu selendang) untuk istri, pesalin orangtua laki-laki (satu tajung, satu baju, satu kopiah, pesalin orangtua perempuan (satu kain, satu baju, dan satu selendang), gong pemali (satu buah talam tembaga), lulung padung (dua meter kain polos), satu set alat salat (engkena dan sajadah).

Begitupula pada ayat lima pelangkat batang bagi perempuan (satu kain, satu baju, satu selendang, satu buah pisau dan sabur) yang kena pelangkah batang adalah bagi adik yang menikah harus sabar punya kakak-kakak perempuan dan ia adalah anak kandung sebapak dan seibu, tetapi tidak sebapak dan seibu tidak mendapat pelangkah batang.

Tradisi inilah yang menjadi corak agama Islam bersandingan dengan budaya. Budaya yang tidak lepas dari masyarakat dan tetap dipertahankan.

\section{Tradisi Beruah}

Selain tradisi seperti buang-buang, tepung tawar, sunatan maupun tradisi pernikahan, adat Desa Nanga Suhaid Kabupaten Kapuas Hulu juga memiliki tradisi beruah. Yang mana tradisi ini dilakukan ketika ada salah satu warga yang meninggal dunia. Setelah dikuburkan, dari pihak keluarga memanggil banyak orang untuk salat magrib berjamaah di rumah almarhum kemudian membaca yasin bersama serta tahlilan dan membaca doa selamat, tolak bala dan doa ruah atau arwah. Kegiatan ini dilakukan selama 14 hari pasca meninggal. mendoakan almarhum untuk tenang di alam kubur serta ditempatkan di tempat yang mulia di sisi Allah. Tradisi ini sama halnya dilakukan oleh masyarakat Bangka Belitung yang dimuat oleh trawangnews (2017) tiap-tiap bulan Syakban, di Belitung Provinsi Bangka Belitung tradisi "beruah" merupakan tradisi yang kerap kali dilakukan sejak zaman dulu, biasanya kegiatan ini diperkirakan bila sudah masuk bulan Syakban. Suku terbesar di Bangka Belitung adalah suku Melayu dan agama terbesar di sana merupakan agama Islam. Tapi dalam tradisi yang dilakukan oleh masyarakat Bangka Belitung tidak diketahui apakah doa-doa tersebut sama dengan doa yang dipanjatkan pada tradisi Desa Nanga Suhaid.

Beruah selalui diiringi dengan salat berjamaah dan tahlilah di rumah almarhum. Tahlilan dipanjatkan mereka dengan mengkhususkan kepada baginda Nabi Muhammad Saw, para sahabat, ulama, dan roh keluarga yang telah meninggal. Walaupun tahlilan tidak pernah dilakukan oleh nabi dan rasul serta sahabatnya tapi untuk menjadikan Islam yang bermoderat menerima akan sebuah kebaikan untuk berdoa dan memanjatkan penghormatan kepada baginda nabi. Juga termasuk suatu yang lumrah karena pada hakekatnya jika kita mendoakan sesama umat muslim, menjalin hubungan serta berlaku sesama akan membuat hidup menjadi tentram. Habibi (24 September 2020) mengatakan kaitan budaya setempat dan agama secara budaya agar saling menyambung silaturahmi sesama kaum kerabat keluarga terdekat secara agama menjelaskan tentang tahlilan, dzikir, dan menggambarkan keberkahan. Kegiatan tahlilan dan yasinan ini juga dilakukan pada acara 
takziyah ketika ada umat Islam yang terkena musibah kematian yang merupakan tradisi yang berkembang di masyarakat Islam (Rhoni Rodin, 2013).

Hal yang menarik dari tradisi ini yaitu kebersamaan untuk menjalin ukhuwah kepada kerabat yang ditinggal kesedihan, kemudian sebagai rasa bela sungkawa kita kepada kerabat tersebut.

Pada tradisi ini keluarga yang meninggal selalu menyiapkan makanan selama 14 hari dengan tujuan untuk sedekah kepada masyarakat setempat agar amal ibadah yang meninggal dunia tetap mengalir dan menjadi amal jariyah. Sebagaimana yang dijelaskan dalam sebuah hadist riwayat Muslim:

Dari Abu Hurairah R.a berkata Rasulullah Saw. Bersabda: "Apabila anak adam itu mati, maka terputuslah amalnya, kecuali (amal) dari tiga ini: sedekah yang berlaku terus menerus, pengetahuan yang dimanfaatkan dan anak shaleh yang mendoakan dia. (HR. Muslim).

Sejalan dengan ini menurut Akbar salah satu remaja masjid (wawancara, 4 Oktober 2020) mengatakan tradisi beruah merupakan salah satu kegiatan yang saling menghargai antara agama dan budaya yang mana kegiatan tersebut masuk dalam kategori shodaqoh dari keluarga yang ditinggalkan, bertujuan untuk menghapus segala dosa arwah yang meninggal, tetapi ada yang berdampak kurang baik yaitu dimana orang yang meninggal dunia atau keluarganya harus mengeluarkan banyak biaya untuk beruah atau tahlilan, sedangkan sebenarnya kita sebagai kaum kerabat harus meringani beban orang yang ditinggalkannya. Akbar juga mengatakan menurutnya ketika beruah biasanya masyarakat melaksanakan salat berjamaah dirumah keluarga yang meninggal atau beruah sebaiknya mengutamakan salat di masjid dan beberapa orang saja yang salat ditempat orang meninggal atau beruah.

Biasanya keluarga menjamukan makanan di hari pertama berupa kue serabi hari kedua kue juadah, setelah hari ketiga jamuan besar berupa nasi dengan lauk ayam atau kerupuk ikan setelah hari ke empat, lima, enam jamuannya berupa kue kembali setelah hari ke tujuh dan ke empat belas berupa nasi tapi sebelum hari ke empat belas jamuannya hanya kue. (Hasan Basri, wawancara Juli 2020). Ritual tersebut sampai sekarang masih simpang siur untuk apakah jamuan makanan yang berbeda-beda sajian pada setiap hari, tapi pada intinya tradisi tersebut sebagai shodaqoh kepada masyarakat yang telah datang ke rumah untuk mendoakan almarhum dan mengucapkan bela sungkawa tersebut.

Dari tradisi tersebut menggambarkan bahwa akulturasi budaya yang dilakukan oleh masyarakat setempat yang menjadikan sebuah hubungan antara masyarakat dengan sesama masyarakat serta hubungan kepada Sang Ilahi selalu terjaga agar menjadi orang-orang yang bertaqwa kepada Allah Swt.

\section{Nilai-Nilai Dakwah}

Dalam tradisi selalu ada nilai-nilai dakwah yang dapat kita ambil. Dakwah menjadikan perilaku Muslim dalam menjalankan Islam sebagai agama rahmatan lil'alamin yang harus didakwahkan kepada seluruh manusia (Hayati, 2017). Dakwahlah yang menjadikan nilai-nilai Islam sangat berarti. Kegiatan dakwah dengan pemurnian aqidah bukan saja sekedar memiliki prinsip dasar keimanan yang kuat tetapi juga dapat mewujudkan prinsip dasar moral dan etika sosial (Nasor, 2017). Tanpa adanya dakwah mungkin hidup tidak terasa indah bagaikan sayur tanpa garam, apa gunanya jika dalam kehidupan tidak merasa manisnya nilai-nilai dakwah yang diberikan. Disamping beberapa prinsip di atas, dakwah Islam sebagai suatu upaya mengajak manusia kepada jalan yang benar dan mempunyai prinsip menjunjung tinggi hak-hak asasi manusia (Wahid, 2011).

Jika kita berpacu pada ulama yang telah berdakwah di tanah Kalimantan Barat seperti halnya Habib Husien Al-Qadrie menyebarkan ajaran agama Islam yang ada di daerah Matan dan Mempawah tidak lain dan tidak bukan karena niat mereka untuk menanamkan nilai-nilai ajaran Islam melalui dakwah. Begitu pula sebaliknya $\mathrm{H}$. Ahmad yang diceritakan oleh Hermansyah melalui bukunya pengembangan Islam di pedalaman Kalimantan merupkan pendakwah yang berhasil menanamkan nilai-nilai dakwah serta tetap mempertahankan tradisi yang telah ada. Nilai-nilai dakwah bukanlah suatu barang yang mati melainkan nilai dinamis yang disesuaikan dengan semangat zaman dan perkembangan ilmu pengetahuan yang ada di masyarakat (Romli, Arwan, dan Irham, 2018). 
Nilai-nilai dakwah yang ada pada tradisi yang sering dilakukan oleh masyarakat Kecamatan Suhaid yaitu Pertama, nilai ukhuwah yang selalu terjaga sehingga menjadi masyarakat yang harmoni. Sebagaimana yang dikatakan oleh remaja masjid Almuttaqien Suhaid yaitu Habibi (wawancara, 24 September 2020) bahwa hal itu akan menimbulkan hubungan silaturahmi. Adanya perasaan ukhuwah dapat menciptakan kekuatan (Quwwah) karena rasa persaudaraan atau ikatan keimanan yang sudah ditanamkan dapat menentramkan dan menenangkan hati yang awalnya gentar menjadi tegar sehingga ukhuwah yang telah terjalin dapat menimbulkan kekuatan yang maha dahsyat (Anshori, 2016). Maka ketika ukhuwah terjaga akan menimbulkan rasa ketentraman pada diri pribadi.

Kedua, nilai adab yang selalu menghormati serta menjaga kerukunan bermasyarakat. Sebagaimana dikatakan oleh salah satu remaja masjid Baitul Rahman Dusun Tanjung Desa Nanga Suhaid yaitu Akbar (wawancara, 4 Oktober 2020) bahwa nilai yang ada pada tradisi nenek moyang yaitu saling menghargai antara agama dan budaya masyarakat. Di Desa Nanga Suhaid para masyarakat selalu menghormati seperti halnya anak muda selalu tunduk ketika mereka bergaul sesama, serta berbicara secara sopan kepada orangtua. Selain itu adab juga mengajarkan masyarakat bertatakrama terhadap hukum adat yang dibuat oleh pemangku adat tentang adat-adat yang berlaku jika adat tersebut tidak dipenuhi maka akan terkena sanksi adat. Sebagaimana dalam hukum adat yang tertera dalam dokumen adat Desa Nanga Suhaid pasal 2 tentang perkara/ masalah (2006) mengatakan bagi setiap orang yang berada di dalam wilayah desa di dalam wilayah Desa Nanga Suhaid, jika mempunyai masalah (perkara) maka orang yang bersangkutan harus dikenakan hukum adat dan membayar uang kesopanan kepada siapa dia melakukan kesalahan. Dengan hukum adat tersebut dapat memperbaiki adab masyarakat setempat. Berbagai krisis yang ada di tengah masyarakat apabila ditinjau dari sudut pandang pendidikan memperlihatkan belum optimalnya pendidikan nasional dalam bentuk masyarakat yang selain memiliki kecerdasan dan keterampilan juga memiliki spiritualitas, pengendalian diri, kepribadian, dan akhlak manusia. (Nurdin, 2015).
Tiga nilai estetika, setiap tradisi tentu mempunyai nilai estetika tersendiri tentang bagaimana caranya menjaga nilai seni akan nikmat yang telah Allah berikan kepada kita. Ketika seni telah menjadi sebuah disiplin (ilmu) dengan struktur khas masing-masing cabang seni akan memberikan gambaran terhadap sistem pemecahan (Sunarto, 2017). Nilai estitika pada desa kecamatan Suhaid yaitu berupa buangbuang yang dibuat dengan corak warna dan bahan-bahan yang tersusun rapi serta tepung tawar yang memiliki seni yang mempertahankan kebudayaan setempat.

Keempat, nilai amal yang terus mengalir saat bershadaqah kepada masyarakat yang berbela sungkawa kepada kaum waris yang meninggal dunia. Sebagaimana dikatakan oleh Akbar (wawancara 4 Oktober 2020) tentang beruah yang merupakan shadaqah dari pihak keluarga yang meninggal. Amal adalah perwujudan dari suatu yang menjadi harapan jiwa, baik berupa ucapan, perbuatan anggota badan ataupun perbuatan hati (Ainiya dan Karsiyah, 2017). Perbuatan tersebut bisa tergambarkan saat masyarakat Kecamatan Suhaid memberikan amalan mereka berupa doa dan juga saat keluarga yang ditinggal memberikan jamuan makanan selama 14 hari sebagai tanda memanjangkan amal perbuatan saat dihisap. Tentu ini merupakan kegiatan yang mulia untuk menjadikan amal selalu bermanfaat bagi akhirat.

Sebagaimana dalam kitab Muttafaqun 'Alaihi menjelaskan:

Barangsiapa yang dihisap, maka ia tersiksa", Aisyah bertanya, "bukankah Allah telah berfirman "maka ia akan diperiksa dengan pemeriksaan yang mudah, maka Rasulullah Saw menjawab, "hal itu adalah al 'aradh. Namun barangsiapa yang dimunaqasyah hisabnya maka ia akan binasa" (Muttafaqun 'alaihi).

\section{Akulturasi Agama dan Tradisi}

Fakta dari akulturasi agama Islam dan tradisi yaitu mau menerima tradisi yang telah ada dari zaman terdahulu. Proses ini merupakan wahana atau area dua buah kebudayaan bertemu, dan masing-masing dapat membawa nilai-nilai bawaannya (Roszi, 2018). Sedangkan budaya selalu ada dalam pertimbangan masyarakat. As will be noted below, spatial considerations are a particular feature of the natural and how to live together (Manghani, 2020). Seperti yang akan 
dicatat bawah ini, pertimbangan spasial adalah khusus karakter yang alami dan cara hidup bersama.

Sebagaimana berkaitan dengan budaya Islam sebagai sistem ajaran agama akan selalu berdialog dengan budaya lokal dimana Islam berada (Nurhuda, 2015). The Phenomenon of multicultural society is, in fact a natural reality that occurs in the process of interactions between people from different cultural groups in the life of modern society (Prasojo, 2013). Fenomena masyarakat multikultur, pada kenyataannya adalah kenyataan alami itu terjadi dalam proses interaksi antara orang-orang dari budaya yang berbeda kelompok dalam kehidupan masyarakat modern. Nilai tersebut berupa akulturasi Islam dan tradisi yang saling memberikan warna pada nilai-nilainya kemudian menjadikan nilai tersebut berkembang di masyarakat dengan cara Islam sendiri seperti halnya doa serta budaya setempat telah menyatu dengan semestinya. Sebagaimana akulturasi yang ada di daerah Jawa. It is less surprising if animism and dynamism, and olso Hind-Buddha, are still effecting "mindset and paradigm" of Javanese people although they have professed Islam as their religion (Muadi \& Sofwani, 2018).

Rasa toleransi antara agama dan budaya selalu terjaga. Toleransi agama merupakan sebuah keniscayaan untuk menjamin stabilitas sosial dari paksaan ideologis atau bahkan bentrokan fisik dalam masyarakat (Casram, 2016). Ketika agama telah masuk dalam budaya rasa toleransi akan timbul seksama, toleransi inilah yang banyak diajarkan oleh para ulama dan pejuang Islam sebagaimana toleransi tersebut dibawa oleh Umar bin Khatab. Ketika berkunjung ke Palestina kemudian masuk ke dalam Gereja mendengar azan ashar beliau keluar salat di luar, ketika ditanya beliau menjawab "saya khawatir kaluar umat Islam mendatang akan merebut Gereja ini menjadi masjid dengan alasan bekas salatnya Umar (Fathurrohman, 2012).

\section{Kesimpulan}

Akulturasi Islam pada tradisi nenek moyang Desa Nanga Suhaid Kalimantan Barat merupakan sikap toleransi antara agama dan budaya. Melalui tradisi adat istiadat yang dimiliki Desa Nanga Suhaid dapat mempertahankan nilai-nilai luhur yang ada di daerah setempat. Upacara adat seperti buang-buang mencerminkan rasa syukur masyarakat Suhaid kepada Allah Swt. Rasa syukur tersebut dapat berupa sedekah kepada alam sekitar dan hewan-hewan yang ada.

Selain itu dalam proses buang-buang selalu diikuti dengan tradisi tepung tawar yang memanjatkan doa dan perlindungan kepada Allah dari warga masyarakat Nanga Suhaid yang ingin melaksanakan hajatan seperti halnya besunat dan pernikahan.

Setelah itu proses tepung tawarpun dilakukan, barulah melaksanakan sunatan yang diiringi dengan pembacaan doa selamat dan tolak bala barulah sang anak resmi dipotong bagian kemaluannya dengan membaca shalawat kepada baginda Nabi Muhammad Saw.

Nilai-nilai dakwah melekat saat kegiatan tradisi tersebut dilakukan pada masyarakat seperti halnya beruah yaitu memanjangkan amal, bersilaturahmi sesama bahkan menjadi masyarakat yang sosial di dalam kehidupan.

Tradisi yang dilakukan Desa Nanga Suhaid Provinsi Kalimantan Barat semata-mata merupakan peninggalan nenek moyang yang mengalami akulturasi melalui Islamisasi daerah pedalaman. Selain itu adat pernikahan juga telah terakulturasi dengan Islam, yang mana Islam mengajarkan pernikahan dengan cara syari'at dan tata cara pernikahan yang dilakukan baginda Nabi Muhammad. Islam juga menerima adat istiadat yang berlaku selama adat tersebut tidak menyekutukan Allah. Akulturasi inilah yang menjadi pandangan Islam bahwa masyarakat Kecamatan Suhaid merupakan masyarakat Islam Melayu yang moderat.

Dari Islam Melayu yang moderat akan menimbulkan masyarakat yang tulus sepenuh hati dalam bersosial. Ketika sosialitas terbentuk akan tumbuh saling kepedulian sesama, kepedulian inilah yang diperlukan untuk kebangkitan bangsa, karena dengan kepedulian kita menjadi satu dan padu dalam menegakkan kebenaran.

Selain itu akulturasi Islam melambangkan suatu keadilan sosial bagi seluruh rakyat di desa tersebut. Dalam hal ini keadilan tersebut berupa sikap tidak saling menyalahkan antara agama dan tradisi yang membuat perpecahbelahan persaudaraan.

Jika perpecahbelahan tersebut terjadi maka akan ada hukum adat yang berlaku pada suatu desa. Hukum adat inilah yang memberi ketegasan 
bahwa sebuah desa adat mempunyai hukum yang harus ditaati dan dipatuhi. Karena jika hukum adat tersebut dilanggar maka sama halnya tidak menghormati peraturan yang dibuat oleh orangorang terdahulu.

Hal yang menarik dari akulturasi Islam dan tradisi budaya Kecamatan Suhaid yaitu masyarakat setempat tidak pernah melepaskan tradisi tersebut walaupun di zaman sekarang kita telah memahami arti kemajuan dalam kehidupan. Bahkan gaya hidup tidak dapat mengubah tradisi yang telah tertanam dalam kehidupan desa.

Inilah yang dinamakan cinta budaya bagaikan memiliki dunia karena setiap kehidupan di desa tidak bisa lari dari masyarakat yang telah mempunyai hak dalam kehidupan. Walaupun kita lari kita akan mengetahui bagaimana tradisi tersebut tergambarkan dalam pikiran kita dan akhirnya kita akan menceritakan tradisi tersebut dengan sesama.

Pada hakekatnya Islam berdakwah dengan cara lembut dan tidak memaksa. Seperti halnya para wali Allah yang diutus dari negeri lain untuk mengajarkan Islam di Indonesa yang menjadikan Islam bernusantara dari berbagai-bagai cara. Karena Islam merupakan agama yang memiliki suatu kepercayaan untuk menegakkan kebenaran serta menjadikan Islam yang rahmatan lil'alamin.
Tentu kita akan berterima kasih kepada Allah Swt yang telah mengutuskan baginda Nabi Muhammad Saw yang telah berdakwah di penjuru negeri dan mengajarkan Islam kepada orang-orang jahiliah sehingga terbentuknya Islam yang di Islamisasikan di berbagai daerah.

\section{UCAPAN TERIMAKASIH}

Ucapan terima kasih kepada Tuhan yang Maha Esa yang telah memberikan kesempatan diri ini pribadi untuk menyelesaikan sebuah penelitian. Kedua kalinya berterima kasih kepada baginda Nabi Muhammad Saw sebagai pedoman hidup berdakwah untuk menegakkan Islam. Dan juga berterima kasih kepada dosen-dosen IAIN Pontianak terhusus Associate Prof. Dr. Zaenuddin Hudi Prasojo yang telah membuka peluang bagi mahasiswa yang ingin bekarya di dunia tulisan sehingga memberikan banyak inspirasi pada dunia pendidikan. Terima kasih juga kepada orangtua saya yang selalu mendukung saya dalam setiap hal yang saya lakukan. Tanpa mereka mungkin saya tidak ada apa-apa, atas ridho merekalah Allah mengizinkan saya untuk terus berkarya. 
Adam, U. K., Yusup, A., Fadlullah, S. F,. \& Nurbayan, S. (2019). Akultrasi BudayaAgama Serta Keselarasan dalam Budaya Sesajen di Kampung Cipicung Girang. Jurnal Pendidikan Sosiologi. Vol. 9, No. 1, Hlm. 37-47.

Ainiyah, Q., dan Karsiyah. (2017). Konsep Kesatuan Iman, Iptek dan Amal Menuju Terbentuknya Insan Kamil dalam Perspektif Pendidikan Islam. Jurnal Istawa Pendidikan Islam, Vol. 2, No. 2, Hlm. 77-114.

Anshori, C. S. (2016). Ukhuwah Islamiyah Sebagai Fondasi Terwujudnya Organisasi yang Mandiri dan Profesional. Jurnal Pendidikan Agama Islam- Ta'lim, Vol. 14, No. 1, Hlm. 117125.

Baehaqie, I. (2017). Makna Semiotis nama-nama makanan dalam sesaji selamatan Tingleban di dukuh Palem, Kabupaten Wonogiri. Jurnal LITERA, Vol. 16, No. 2, Hlm. 203-216.

Bangun, D., dan Berutu, L. (2013). Tradisi Khitanan (rekontruksi pengetahuan dari Paraktik Khitan pada Pria Non Muslim di Kota Medan). Jurnal Fisip UNAND, Vol. 1, No. 2, Hlm. 412-417.

Casram. (2016). Membangun Sikap Toleransi Beragama dalam Masyarakat Plural. Jurnal Ilmiah Agama dan Sosial Budaya, Vol. 1, No.2, Hlm. 187-198.

Dokumen Hukum Adat Kecamatan Suhaid (2016).

Effendi, Z. (2017). Penyiaran Islam di Daerah Perbatasan "Badau" Indonesia-Malaysia. Jurnal Penangkaran, Vol. 1, No. 1, Hlm. 1-18.

Fathurrohman. (2012). Aswaja NU dan Toleransi Umat Beragama. Jurnal Review Politik, Vol. 2, No. 1, Hlm. 34-45.

Hadist Riwayat Muslim. Amalan yang tidak Terputus Hingga Setelah Meninggal. http:// darunnajah.com. Diakses Juli 2020.

Hasbullah, Tayo, dan Pawi, A. A. A. (2017). Ritual Tolak Bala pada Masyarakat Melayu (Kajian pada Masyarakat Petalangan Kecamatan
Pangkalan Kuras Kabupaten Pelalawan. Jurnal Ushuluddin, Vol. 25, No. 1, Hlm. 83100.

Hermansyah. (2012). Pengembangan Islam di Pedalaman Kalimantan. Pontianak: Stain Press.

Ibrahim. (2018). Contiguity of Islam and Local Tradition on The Hinterland Malays of west Kalimantan. Journal of Islamic Studies, Vol. 22, No. 2, Hlm. 277-300.

Ibrahim. (2015). Metode Penelitian Kualitatif. Bandung: Alfabeta.

Indradjaja, A. (2014). Awal Pengaruh HinduBuddha di Nusantara. Jurnal Kalpataru, Majalah Arkeologi, Vol. 23, No. 1, Hlm. 17-33.

Kurniawan, S. (2018). Globalisasi, Pendidikan Karakter dan Kearifan Lokal yang Hybrid Islam pada Orang Melayu Kalimantan Barat. Jurnal Penelitian, Vol. 12, No. 2, Hlm. 317-354.

Manghani, S. (2020). Neutral Life: Roland Barthes' Late Work An Introduction. Journal Sagepub, Vol. 37, No. 4, Hlm. 3-34.

Muadi, S., \& Ahmad Sofwani. Acculturation of Islam and Javanese Culture in Public Servant Ethicts. Jurnal El-Harakah, Vol. 20, No. 2, Hal. 233-252.

Mumtazul. (2017). Relasi Antarumat Beragama pada lembaga pendidikan: studi kasus pada perguruan Kristen Methodist Banda Aceh. Jurnal Penanas Vol, 30, No. 2, Hlm. 195-214.

Muttafaqun 'Alaihi. Hisab pada Hari Pembalasan. Https://almanhaj.or.id. Diakses Juli 2020.

Nasor, M. (2017). Implementasi Nilai-Nilai Dakwah dalam Membina Masyarakat Pluralitas di Jati Agung Lampung Selatan. Jurnal Al-Adyan, Vol. 12, No. 2, Hlm. 159-188.

Nurhuda. (2015). Akulturasi Islam Budaya lokal dalam tradisi "menyumpet" di Desa Sekuro Kecamatan Mlonggo Kabupaten Jepara. Jurnal Ilmu Dakwah, Vol. 35, No. 2, Hlm. 287306. 
Nuryah. (2016). Tedhak Siten: Akultrasi Budaya Islam-Jawa (Studi kasus di Desa Kedawung, Kecamatan Pejagoan, Kabupaten Kebumen). Jurnal Fikri, Vol. 1, No. 2, Hlm. 315-334.

Nurdi, I. F. (2016). Perbandinhan Konsep Adab Menurut Ibn Hajar Al-'Asqalany dengan Konsep Pendidikan Karakter di Indonesia. Jurnal pendidikan Islam, Vol. 4, No. 1, Hlm. 159-187.

Nuriyanto, L.K. (2017). Kerukuran Umat Beragama di Kota Surakarta: Studi Kasus Relasi Antara Masjid Al-Furqon dan gereja Bethel Injil Sepenuh "Nafiri Sion" Karangturi. Jurnal Penanas Vol. 30, No. 2, Hlm. 145-162.

Oktavia, L. (2014). Circumcision and Muslim Women's Identity in Indonesia. Studia Islamika, Vol. 21, No. 3, Hal. 419-458.

Prasojo, Z. H. (2013). Indigenous Community, Customary Law and Multiculturalismne in Indonesia. Jurnal Al-Albab, Vol. 2, No. 1, Hlm. 99-110.

Rodin, R. (2013). Tradisi Tahlilan dan Yasinan. Jurnal Kebudayaan Islam. Vol. 11, No. 1, Hlm. 76-87.

Roszi, J. P. (2017). Akulturasi Nilai-Nilai Budaya lokal dan Keagamaan dan Pengaruhnya Terhadap Perilaku-Perilaku Sosial. Jurnal Kajian KeIslaman dan Masyarakat, Vol. 3, No. 2, Hlm. 171-198.

Royyani, M.F. (2014). Tepung Tawar Keanekaragaman Hayati dan Jejak Budaya di Pegunungan Meratus. Jurnal Biologi Indonesia, Vol. 10, No. 2, Hlm. 213-219.

Sunarto. (2017). Estetika dalam Konteks Pendidikan Seni. Jurnal Refleksi Edukatika, Vol. 7, No. 2, Hlm. 102-110.

Saripaini dan Yusriadi. (2016). Identitas orang Bugis di Dabong, Kalimantan Barat. Jurnal Khatulistiwa, Vol. 16, No. 2, hlm. 170-182.

Sutiyono. (2011). Tradisi Masyarakat Sebagai kekuatan Sinkretisme di Trucuk, Klaten. Jurnal Penelitian, Vol. 16, No. 1, Hlm. 45-59.

Umi Hayati. (2017). Nilai-Nilai Dakwah: Aktivitas Ibadah dan Perilaku Sosial. Jurnal Inject. Vol. 2, No. 2, Hlm. 175-192.
Wahid, A. (2011). Nilai-Nilai Universalitas Dakwah dalam Al-Qur'an. Jurnal Islamica, Vol. 5, No. 2, Hlm. 383-394.

Widati, S. (2011). Tradisi Sedekah Laut di Wonokerto Kabupaten Pekalongan: Kajian Perubahan Bentuk dan Fungsi. Jurnal PP Vol. 1, No. 2, Hlm. 142-148.

www.trawangnews.com/tradisi-beruah. Diakses Juli 2020.

Yusriadi. (2018). Identitas Dayak dan Melayu Kalimantan Barat. Jurnal Handep. Vol. 1, No. 2, Hlm. 1-16.

Yusriadi. (2014). Sejarah dan Perkembangan orang Melayu di Riam Panjang, Kalimantan Barat. Jurnal Khatulistiwa. Vol. 4, No. 2, Hlm. 148168. 
